\title{
O TEATRO DE OSWALD DE ANDRADE - IDEOLOGIA, INTERTEXTUALIDADE E ESCRITURA
}

\author{
Elisa Guimarães ${ }^{1}$
}

CURY, José João. O teatro de Oswald de Andrade - ideologia, intertextualidade e escritura. São Paulo: Annablume, 2003.

É um lugar comum dizer-se que toda obra de arte pode ser interpretada segundo perspectivas diferentes, nenhuma das quais completa, embora muitas sejam válidas. Nesse exercício de interpretação, corre-se o risco de prestar tributo à limitação de uma perspectiva e acaba-se por falsear a obra.

No entanto, há recortes que, se sabiamente apreendidos, passam a funcionar como sínteses perfeitas da essência da obra em análise.

É o que o leitor pode inferir quando da leitura de $O$ teatro de Oswald de Andrade - ideologia, intertextualidade e escritura, de José João Cury.

Entre a didática do professor e a visão percuciente do pesquisador,desdobram-se considerações sobre o escritor Oswald de Andrade tomando posição perante o seu tempo, dirigindo-se a seus contemporâneos, assumindo sua responsabilidade de militante na sociedade. Analisa-se o dramaturgo que transcende as condições que o circundam e afirma sua liberdade numa literatura comprometida.

Munido de sólido instrumental teórico e respaldado na intertextualidade de três peças oswaldianas - O rei da vela, O homem e o cavalo, A morta - José João Cury explora a construção do texto dramático que ele vê como "uma produção de ideologismos", integrando-se os dados que o constituem num encadeamento de natureza social, cultural, histórica e filosófica.

Processo relacional e mimético por excelência, a intertextualidade oferece margem para a exploração dos diversos procedimentos configuradores da intersecção dos textos. Assim, por exemplo, a peça $O$ rei da vela é analisada à luz de uma relação intertextual com o discurso marxista, enquanto $A$ morta identifica-se como um "discurso apocalíptico, destruidor da cultura burguesa".

O autor-professor, testemunhando seu convívio com a boa didática, define e exemplifica com extrema clareza recursos integrados à rede intertextual, tais como carnavalização, menipéia, paródia, estilização, paráfrase. Recolhe das três peças em pauta passagens magistralmente elucidativas dos princípios teóricos que lhes servem de embasamento. Aponta Oswald de Andrade como escritor "vigoroso e virulento", inspirado em autores da estirpe de Marx, Engel, Lênin, Stalin, Trotsky. Remove, assim, da obra oswaldiana, a cortina discursiva que tolda os vários estratos das três peças em estudo: desaloja o processo ficcional e preenche o claro com a percepção da consciência civil do dramaturgo. Desvenda-lhe a ideologia ou as muitas tendências estruturantes das peças - surrealismo, anarquismo, marxismo, futurismo, dadaísmo, surrealismo, cubismo etc.

\footnotetext{
${ }^{1}$ Universidade de São Paulo e Universidade Presbiteriana Mackenzie.
} 
Vigora, pois, como bem demonstra o autor, o aspecto ideológico na trajetória dramatúrgica de Oswald de Andrade.

Buscando, por intertextos, uma unidade na diversidade das propostas do autor, a fim de identificar as ideologias, José João Cury manipula, com justeza e competência, os textos que se intertextualizam como formas de adesão, de complementaridade ou de refutação às idéias veiculadas. Interpreta, por exemplo, a peça $\mathrm{O}$ homem e o cavalo como negação do tragicômico visível em $O$ rei da vela.

Nessa mesma peça, rotulada de "paródia da História Universal", menciona "revolução" como termo recorrente - esta palavra parecendo fazer parte do vocabulário oswaldiano. Mas não como estigma ou labéu. E sim como título. Certamente, Oswald de Andrade desvanecia-se por ser revolucionário. Experimentava o gosto da ruptura, do protesto e estendia esse gosto à sua maneira de ser e de expressar-se.

Define-se ainda essa mesma postura pela seleção de determinados papéis a serem desempenhados pelas personagens. Assim, no personagem Pinote desenha-se a paródia do intelectual - no dizer de José João Cury, "burguês farsante, representante de uma classe desengajada, neutra".

A maneira como o autor analista conduz as etapas da análise incita o leitor a perguntar: "Para o escritor, onde acaba a realidade? Onde começa a ficção? Talvez realidade e ficção sejam inseparáveis. Certamente, os fatos da realidade são como tijolos -argamassados, transformam-se em parede, pelo saibro, pela cal, pelo reboco da verossimilhança - manipulados pela imaginação criadora".

No rastro ainda dessa imaginação criadora, ergue-se, pelo primor da análise, a figura de Oswald de Andrade cujas peças revelam um partidarismo apaixonado, um pathos profundamente crítico. São condições que, certamente, permitem a uma obra transcender o momento histórico-geográfico em que nasceu e atingir, por isso, uma eficácia duradoura e uma dimensão universal.

Em estilo perfeitamente apropositado, sem a menor indecisão expressional, manso e liso, de acabamento exato, José João Cury sintetiza, nessa sua análise magistral, os ensinamentos que vem ministrando na Escola de Comunicação e Artes da Universidade de São Paulo, bem como no Programa de Letras dos Cursos de PósGraduação da Universidade Presbiteriana Mackenzie, onde é professor.

Outro estimável valor acrescenta-se aos muitos méritos do professor autor: a Apresentação feita pela professora Nanci Fernandes que, em sábias reflexões, explora os recursos múltiplos oferecidos por Oswald de Andrade, ao lado de José João Cury. 